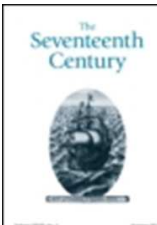

\title{
A Royalist Mathematical Practitioner in Interregnum Oxford: The Exploits of Richard Rawlinson (1616-1668)
}

\begin{tabular}{|r|l|}
\hline Journal: & The Seventeenth Century \\
\hline Manuscript ID & RSEV-2017-0022.R1 \\
\hline Manuscript Type: & Original Article \\
\hline Kate Submitted by the Author: & 02-Oct-2017 \\
\hline Complete List of Authors: & Poole, William; Oxford University, English \\
\hline \multicolumn{2}{|c|}{} \\
\hline $\begin{array}{l}\text { Civil War Oxford, Early modern mathematicians, Richard Rawlinson, } \\
\text { Queen's College, Oxford }\end{array}$ \\
\hline $\begin{array}{l}\text { Note: The following files were submitted by the author for peer review, but cannot be converted to } \\
\text { PDF. You must view these files (e.g. movies) online. }\end{array}$ \\
\hline $\begin{array}{l}\text { Rawlinson fig 3.jp2 } \\
\text { Rawlinson fig 4.jp2 } \\
\text { Rawlinson fig 5.jp2 }\end{array}$ \\
\hline
\end{tabular}




\section{A Royalist Mathematical Practitioner in Interregnum Oxford: The Exploits of Richard Rawlinson (1616-1668)}

The English universities were under attack in the early 1650s: questions were being asked around the country about how useful, how modern, and how godly they and their products were. An Oxonian response to some of these criticisms came in the form of the Vindiciae Academiarum, published in 1654 in that city under disguised names, but authored by John Wilkins, Warden of Wadham, who was responsible for the preface, and Seth Ward, Savilian Professor of Astronomy, who wrote the body of the text.

Given Ward's professorial role in the university, astronomy received

understandably prominent treatment in the Vindiciae, culminating in Ward's claim that:

... I believe there is not one man here, who is so farre Astronomicall, as to be able to calculate an Eclipse, who hath not received the Copernican System, (as it was left by him, or as improved by Kepler, Bullialdus, our own Professor [i.e. Ward himself], and others of the Ellipticall way) either as an opinion, or at leastwise, as the most intelligible, and most convenient Hypothesis. ${ }^{1}$

This advertisement, its conclusion modulating fashionably into mitigated scepticism, implies a body of mathematically literate dons, and one with quite a high entrance bar, namely the ability "to calculate an Eclipse."

Thanks to the work of, in particular, Mordechai Feingold, we now know who many of these mathematical dons were. ${ }^{2}$ The purpose of the present article is to track the career of a hitherto rather obscure example of these academic mathematical practitioners, namely Richard Rawlinson of The Queen's College, Oxford, a man interested not only in trigonometry and eclipse observation, but also a defiant Royalist who used his mathematical skills to assist the king's cause in Civil War Oxford. Rawlinson subsequently managed to survive in Interregnum Oxford, probably by absconding when the Parliamentary Visitors arrived in 1648 with their difficult questions; and yet his correspondence in the 1650s also reveals Rawlinson's links with Samuel Hartlib, the London intelligencer often associated with the Parliamentary regime. There is no indication Rawlinson ever cooled in his political allegiance to the crown, but, like many others, he found a modus vivendi based not on defection but on a pragmatic reconcentration of his energies elsewhere. Below is presented first a brief biography of Rawlinson, and then an investigation of his mathematical and astronomical activities in the 1640s and 1650s, the period of Rawlinson's significant activity.

\section{I.}

Richard Rawlinson was born in the market town of Milnthorpe, Westmorland, probably in 1618. He entered Queen's as a plebeian from a family without any evident prior university participation. In the period Milnthorpe was part of the parish of Heversham, and Rawlinson was presumably educated at the Heversham grammar school, founded very recently in 1613 by Edward Wilson of nearby Nether Levens. ${ }^{3}$ In 1622, when contributions to the crown were sought from the clergy and schoolmasters toward the recovery of the Palatinate of the Rhine, one Mr Wakefield of Heversham, as schoolmaster, paid $£ 1$. This was James Wakefield, graduate of Queens' College Cambridge, who served as both curate and schoolmaster at Heversham from 1621 until 1626, when he moved to Windermere as vicar; the vicar at Heversham throughout this period, Thomas Calvert, was an absentee, and an unpopular one at that. ${ }^{4}$ Perhaps therefore Rawlinson was taught by Wakefield briefly, and then by his successor, if the 
man next named as curate, Richard Hudson, again doubled, as was typical at the time, as the schoolmaster. This Hudson is identifiable with the Richard Hudson of Westmorland who matriculated as a plebeian at Queen's, Oxford, on 26 October 1621, aged seventeen, although no subsequent degree is recorded for this man. ${ }^{5}$ The schoolmasters of Heversham were paid the reasonable salary of $f^{20}$ p.a., and theirs proved to be an intermittently noteworthy school: two generations after Rawlinson, for instance, Heversham produced Ephraim Chambers, author of the Cyclopedia. Moreover, there was a traditional preference at Queen's for candidates from Cumberland and Westmorland, and although this was not the only tie between the college and the schools in those regions, ${ }^{6}$ Wilson's Heversham endowment had provided for scholarships between his school and Queen's, additional if circumstantial evidence that Rawlinson indeed attended the Heversham school. ${ }^{7}$

Rawlinson matriculated as a batler at Queen's, Oxford, on 3 June 1636, giving his age as eighteen, and received his BA on 25 February 1641, the normal period of study for that degree. Among the seniors at Queen's were the diarist Thomas Crosfield (matr. 1618), and Thomas Barlow (matr. 1625), who would become Bodley's Librarian in 1652 before moving on to yet higher things. In 1640 Rawlinson was elected a Taberdar, a class of scholars on the foundation, i.e. on scholarships, but who were between the degrees of BA and MA and so were not yet eligible for fellowships. Unusually, the Taberdars had their own library, which had been set up probably as early as the 1620s; perhaps significantly, this soon included a copy of Clavius's edition of Euclid, donated by Rawlinson's contemporary (and perhaps his tutee?), the markedly royalist Clement Ellis; as we shall later see, some of Rawlinson's own manuscripts ended up in this library too. ${ }^{8}$ The fellows' library, which would soon be open to Rawlinson, had only a handful of manuscripts at this date, but the printed library was growing in this period. ${ }^{9}$

Oxford life, however, was transformed following the Battle of Turnham Green on 13 November 1642, when Charles I's attempt to march on London was successfully blocked by the Parliamentary army. Charles and his troops were forced to withdraw back to Oxford, which became Charles's headquarters for the rest of the first civil war, until the Royalists surrendered the city in June 1646. One of the first things Charles did upon occupying the city was to refortify it, and Rawlinson, despite his hitherto merely scholastic credentials, soon placed his mathematical abilities at the service of the royalist command. As the antiquary Anthony Wood recorded,

The Works and Fortifications also did now go on apace, and those in St Clement's Parish, on the East side of Oxford, were about this time begun. Which, with other Fortifications about the City, were mostly contrived by one Richard Rallingson, Bach. of Arts of Queen's College, who also had drawn a Mathematical Scheme or Plot of the Garrison. His endeavours in this nature gave so great satisfaction to the King, that he forthwith sent Letters in his behalf to the University, to confer the Degree of Master of Arts upon him, Which letters being read in Convocation 17 Octob. was then admitted Master of Arts. ${ }^{10}$

Wood's source is the transcript of the letter itself, which he had read in the Register of Convocation, and which he is paraphrasing accurately. ${ }^{11} \mathrm{He}$ also came across, seemingly separately, a scheme of the fortifications, and this representation, at the instigation of John Fell of Christ Church, was engraved and printed in Wood's 1674 Historia et Antiquitates Universtitatis Oxoniensis under the title "Ichnographia Oxoniae." The "Ichnographia" was printed with the date "1648," which Wood himself emended to the more plausible "1646" in his own copy of his book. This engraving has become one of the best-known depictions of Oxford in the Civil War. ${ }^{12}$ 
But what does this illustration actually represent? When reviewing the matter in his later Fasti Oxonienses, Wood claimed that an "ichnography" had in fact been drawn up by Henry Sherburne, MA, Controller of Ordnance in the army of Lord Hopton, for the royalist army officer Sir Thomas Glemham, who only arrived in Oxford in November 1645. (Sherburne himself was killed in action in 1646.) Wood commented that it was this "or another drawn by Rich. Rallingson" which had been engraved for the Historia. ${ }^{13}$ Subsequent research has demonstrated that the engraving in Wood's Historia is indeed derived from Rawlinson's drawing, and that this plan formed the basis for the fortifications then undertaken by Charles Lloyd, engineer in charge of the work. He was succeeded by Dietrich Boekman and finally Bernard de Gomme. De Gomme's defences were "newly finished" in 1646, and this, I suggest, explains Wood's slightly misleading emendation of the already incorrectly dated Rawlinson plans to that year. Rawlinson, therefore, drew up the initial proposal, with its distinctive double line of defences; significant works, informed by but certainly not depending on this ambitious scheme, were subsequently undertaken by the professional engineers; and Sherburne, in a now lost piece, depicted what had actually been constructed towards the end of the process. ${ }^{14}$

Rawlinson's scheme is unmistakeably bookish in its inspiration, amounting to a partly idealised imposition of a regular array of bastions around the city. By 1620, the Bodleian held at least ten major works in Latin, Italian, or French on fortification, most of them finely illustrated with comparable schemes of single, double, or even triple lines of fortifications. ${ }^{15}$ One would not need to seek far among even recent manuals in English-Henry Hexham's translation of Samuel Marolois' The Art of Fortification (Amsterdam, 1631), for instance, or Richard Norwood's Fortification or Architecture Military (London, 1639)— to find yet more designs for double fortifications with bastions.

In 1643 Rawlinson became a fellow of his college: he first appears in the annual accounts for 1643-44, salaried at $£ 1$, the lowest kind of payment. The next year his stipend rose to $f 4$, and he was paid this sum annually by the college every year to 1665 66, without exception. ${ }^{16}$ In 1643 too he was allowed by his college to defer his ordination, otherwise required by the statutes, evidently because of wartime worries about the future direction of the church. Rawlinson seems to have relented, however, as, having become a deacon on 16 June 1644, he finally took full orders on 11 April 1646, clandestinely ordained by the Bishop of Oxford, Robert Skinner, in the chapel of Trinity College, one of the four or five hundred secret ordinations Skinner carried out thus. ${ }^{17}$ When the Parliamentary Visitation came to Oxford, however, Rawlinson had very probably withdrawn from the city. For on 20 June 1646, a few days before the final evacuation of Royalist forces from the town, Rawlinson was rather unusually granted dispensation by his college to absent himself for a year, "et ulterius ... si necesse fuerit" ("and even longer should it prove necessary"). ${ }^{18}$ Thus his name is entirely absent from the Register of the Visitors. ${ }^{19}$

Rawlinson's departure was indeed only temporary, and like several other obviously Royalist college colleagues, he somehow managed to survive the Interregnum without either ejection or public capitulation. We hear of him again in the records of the college in 1650, when Rawlinson served as "Magister puerorum" (i.e. he oversaw the education of the "Poor Boys" or choristers of the college); in 1653 we find him visiting a school under the college's control, namely that of Northleach in Gloucestershire; and between 1652 and 1660 he served three times as one of the two college treasurers. ${ }^{20} \mathrm{He}$ had his own tutorial pupils, of which at least one became a major scholar, namely Lancelot Addison, whose 1657 terra filius speech was so anti-puritan he was forced to retract it in Convocation on his knees. ${ }^{21}$ A character sketch of Rawlinson as a don survives in a letter from his head of house, Gerard Langbaine, to John Milles, to whom 
he sent an account in 1648 of all the fellows in his charge. "Rallingson" was the eighth in the list:

Mr Rallingson is a very excellent yong man, extremely studious, a general Scholar; but a most eminent Mathematicien. The Earle of Kensington took such a likeing to him here, that when he went from hence he wold needs have him along with him. and although I severall times attempted to gaine him againe, yet my lord putts such a price upon him as he will not yet be entreated to part with him. Thus much you may read in his Lordships lettres to me; I have some others of the same Kind. He was not present when the rest of our College were summon'd, nor has he been here since. I a sumainted him with the sum the time was elapsed before he receiued any notice $\&$ the sentence (as I was enform'd by your self at Westminster) passed in generall \& therefore I could not tell what to advise him in particular. The man is knowne to Mr Budden the Proctor who I presume will give him a fire testimony. I have added a letter of Mr Rallingsons owne concerning his appearance. ${ }^{22}$

In other words, with college contrivance, Rawlinson had absconded under aristocratic protection. The reference to "the Earle of Kensington" is a little puzzling, and might just refer to Henry Rich, created Baron Kensington in 1623, but then Earl of Holland in 1624, and finally executed in 1649. But there is conflicting evidence, and from the same source, that Rawlinson was actually with Henry Pierrepont, Marquess of Dorchester, in this period, and this problem will be addressed later.

It is significant that by 1648 Rawlinson could be described as "a most eminent Mathematicien," and it was from the mid 1640s to the mid to late 1650s, indeed, that most of Rawlinson's recoverable work in mathematics and astronomy took place. Queen's itself was a congenial place for such activities, and Rawlinson's younger contemporaries included Joseph Williamson (matr. 1650), and Robert Southwell (matr. 1653), both future Presidents of the Royal Society. ${ }^{23}$ Rawlinson himself soon became part of the network of scientific gatherings that characterizes 1650s Oxford. ${ }^{24}$ Seth Ward reported to Sir Justinian Isham in 1652 that a "Clubb" of "about 30 persons" was, in addition to performing certain experiments, working through the Bodleian's holdings "to gather together such things as are already discovered and to make a booke with a general index of them," in order to compile "an history of the phenomena." Lists of who took part in this ambitious project and for what ranges of shelfmark they were responsible were compiled by Langbaine of Queen's, and "Rallingson" appears in these lists three times. ${ }^{25}$ At this time too we find him in the company of John Wallis and the young Christopher Wren, observing eclipses. Rawlinson, as mentioned, also made contact with Samuel Hartlib, the prominent London intelligencer, and among the Hartlib Papers survive a handful of letters from or concerning Rawlinson and his work. Finally, Rawlinson took the unusual but not unprecedented step for a don of engraving his own work, both in eclipse observation and in trigonometry. ${ }^{26} \mathrm{We}$ shall return to these activities and their reception in the second half of this essay.

Rawlinson kept his fellowship at Queen's throughout the 1650s, yet after the Restoration he failed to rise to the prominence Wood retrospectively thought he had deserved: he "had not preferment confer'd on him equal to his merits." 27 At the New Year's meeting on 2 January 1661 of the newly founded Royal Society, he ("Rawlinson," no first name given) was proposed as a fellow, alongside Edmund Waller, Charles Scarborough, Peter Pett, Daniel Colwall, and William Coventry; but when this batch came to be elected a fortnight later, Rawlinson's name had disappeared from the list, 
never to reappear. ${ }^{28}$ Assuming this is the right Rawlinson, nothing further can be said about this curious failure.

Rawlinson fared better at Oxford, where he was created DD on 9 September 1661, "while the chancellor [i.e. Edward Hyde, Earl of Clarendon] held the supreme chair in convocation," as Wood recorded. ${ }^{29}$ This was a memorable occasion: the same ceremony saw the creation of several young masters, including the chancellor's son, Edward, and his godson, John Wilmot, Earl of Rochester, as well as Matthew Wren, son of Matthew Wren the Bishop of Ely, and Matthew Dugdale, son of William Dugdale the herald and antiquary. ${ }^{30}$ Wood also stated that at this point Rawlinson was a chaplain to the Duke of Newcastle, a claim otherwise unsubstantiated. ${ }^{31}$ This is a pity, for it could place Rawlinson in contact with the Duke's wife Margaret Cavendish, the literary writer and natural philosopher who also cultivated Barlow of Queen's. (I suspect, however, that Wood may here have confused Rawlinson with Clement Ellis, who was indeed appointed domestic chaplain to Newcastle at the Restoration.) That Rawlinson was "created" and not "admitted" DD, in the technical language of the academe, shows that this was an honorary degree, in recompense for service and loyalty.

Rawlinson is next encountered in 1662 as the private tutor to Josceline Percy, son and heir of Algernon Percy, $10^{\text {th }}$ Earl of Northumberland, when Rawlinson had to subscribe to the Act of Uniformity. ${ }^{32}$ Rawlinson must have continued his residence in Oxford in these years, for in the college accounts for the year 1663-64, we find the payment, fascinatingly, of $f_{1} 111 s 6 d$ “Ægidio Syvers pro opere circa domum a Doctore Rallison [sic] astris obervandis designatam" ("to Giles Syvers for work on the room appointed by Dr Rawlinson for stargazing"), dated to 7 November $1663 .{ }^{33}$ Nothing else of this brief Restoration observatory is known.

Rawlinson's chaplaincy seems unlikely to have been significantly remunerated, and as we saw he continued to draw his college stipend. On 22 December 1665, however, he was appointed Rector of St Mary's, Pulborough, in West Sussex. This living was worth $£ 20$ a year in the period, towards the upper end on the local scale, but still not very much money. ${ }^{34}$ On 1 December the following year he was licensed to marry Bridget Croke, who was said to be about twenty-two at this date. ${ }^{35}$ He did not survive very long, however, as on 20 July 1668 he made his will, appointing as his executor his brother-inlaw Walter, son of Christopher Nicholson of Poulton near Lancaster. ${ }^{36}$ The will, which was proved only nine days later, is a gruff document. Rawlinson gave $£ 3$ to the poor of his parish, and $f 5$ to Queen's for plate. To his "deare" wife Bridget went most of the household goods she had brought with her to the marriage, but emphatically nothing else. Rawlinson inveighs against his wife's family and friends, and also the "unreasonable incorrigible folly" of his sister and brother-in-law, whom he accuses of "misus[ing] mee and my whole estate." His comments on his wife's family, the Crokes of Chequers, suggest that they had regarded their son-in-law as somewhat déclassé. ${ }^{37}$ (Theirs was indeed the Chequers now occupied as a country retreat by the serving Prime Minister.) Bridget's parents had evidently settled large sums on the daughter prior to marriage, and Rawlinson complained of how "Jealous and pressing," how "prejudiciall" this act had been (and against his advice), regretting that he now cannot bestow the $f, 500$ legacy demanded by his in-laws on his still "deare" wife. Unfortunately Rawlinson mentioned no books or mathematical instruments in his testament.

Various members of the mathematical community noted Rawlinson's death. John Collins wrote to John Pell on 23 October 1668, remarking that "Dr Rawlinson as likewise the Earle of Northumberland [the father of Rawlinson's sometime private student] are lately dead"; Pell responded on the $28^{\text {th }}$ that "Dr Rawlinson could write very faire and grave neatly: It is not unlikely that he hath left some exercises ready for the press." ${ }^{\text {"38 }}$ A few years later Francis Vernon must have enquired after Rawlinson's papers 
too, for in a response, John Collins discoursed at length about Rawlinson, in alas damning terms: "I knew the author too well to believe that any thing of his is worth the printing, and I find Bishop Ward and Dr. Pell to be of my mind." ${ }^{39}$ He then followed this with an anecdote about a "comment" (i.e. commentary) on William Oughtred's Clavis Mathematica (1631, five Latin editions to 1693) written by Rawlinson, and its author's inability to solve the problems of Oughtred's nineteenth chapter by means other than "four several tedious analytic calculations" ("analytic" may hint that Rawlinson was, in Collins's view, more wedded to algebra than geometry). So Rawlinson, one of at least four Englishmen around this time to do so, had written a commentary on Oughtred's Clavis, albeit one considered pedestrian by Collins. ${ }^{40}$ As for Rawlinson's books and papers, Collins could report that a bookseller, "Isles" of Duck Lane, as well as "Anderson" and "Streete," had bought his printed books, but not his original papers; Collins said that "with no great appetite" he would ask Streete about the latter, "for which a great rate was demanded." These men are (possibly) William Iles, bookseller, (certainly) Robert Anderson, weaver and mathematician, and the astronomer Thomas Streete. ${ }^{41}$ Vernon nevertheless persisted, as Collins wrote to him on 14 December 1671 that Edward Bernard in Oxford had informed him that the Rawlinson papers not sold with his books were in the hands of Alan Carr or Carre, fellow of All Souls and junior proctor for 1671, but contained "nothing ... desirable being but Excerpta from Euclid[,] Herigon and Oughtreds Clavis." "This at least confirms Rawlinson's interests in Oughtred, and the mention of "Herigon" is suggestive, as the French mathematician Pierre Hérigone (1580-1643) was known chiefly for his many notational innovations.

The news about Rawlinson's papers somehow reached Humphrey Nicholson, the man who had been named in Rawlinson's will as brother to his executor Walter, as Humphrey wrote to Collins on 6 April 1672 declaring that he was now the "nearest relation and alsoe the Executor" to Rawlinson, which presumably means that Walter had died in the interim. Humphrey had heard that a "friend" of Collins at Oxford had recently had sight of Rawlinson's manuscripts, and was writing to reclaim them as their lawful owner. ${ }^{43}$ We do not know if this ever transpired, but there are in the library of Queen's today a set of eight manuscripts, to be analyzed shortly, that are very probably these sought-after papers.

II.

Seth Ward, we saw at the opening of this article, was especially keen to advertise Oxonian proficiency in his own subject, astronomy. He had been appointed Savilian Professor of Astronomy in 1649, and, invited to reside in Wadham College by John Wilkins, he soon enrolled as a fellow commoner of the college. In probably 1651, he set about converting the Tower of Wadham into an observatory. Ward was granted considerable sums from the Savilian Chest to do so- $13 \mathrm{~s} 6 \mathrm{~d}$ for mending a quadrant and making a declinatory ring, and $£ 253 s$ for purchasing other fittings required for what he described a "mobile" observatory — despite the fact that this was a move from the tower that had served as the university's observatory for the previous three decades, namely the Tower of the Five Orders in the old Schools Quadrangle. ${ }^{44}$ This had hitherto been the home of the Savilian Professors, as well as their books and instruments.

Ward was diligent in lecturing and offering more practical instruction in the mathematical arts, as well as publishing various works in astronomy, trigonometry, and the Vindicia Academiarum, as his friend and biographer Walter Pope recalled. ${ }^{45}$ His fellow Savilian was John Wallis, who had been appointed, also in 1649, to the paired chair in geometry. Both had started their careers in Cambridge, and both proceeded DD at the same time in Oxford, in 1654, Wallis claiming seniority, to the irritation of Ward and his 
biographer—although Pope was anxious to insist that "this slight difference bred no Animosities." 46

Wallis himself insisted on carrying out astronomical observations too. The most important of these for our purposes was the observation of a solar eclipse on, according to the Julian calendar, 2 August 1654 - the very same eclipse that fell over the Battle of Shklow on 12 August (by the Gregorian calendar), one of the opening engagements of the Russo-Polish War of 1654-67. The Oxonian astronomers knew about the eclipse from their tables, and three of them gathered early in the morning to observe it. They were led by Wallis, who did not find it hard to assume personal dominance of any situation. He later published an account of their vigil as part of his Operum mathematicorum pars altera (Oxford, 1656), dedicating this section of his book to the great Danzig astronomer Johannes Hevelius (1611-87). ${ }^{47}$

Wallis regarded himself as the principal observer, assisted by two other men "most expert in mathematical matters." These were the younger dons Christopher Wren, of future fame but then a mere Fellow of All Souls, and Richard Rawlinson. (Both, as ardent royalists, must have found a way of working with that Parliamentary intrusion, Wallis, based on shared non-political interests.) Wallis explained how they had set up a telescope in a dark room, just as he had done when observing an eclipse two years previously (29 March 1652, to be precise). The telescope was oriented so that it would project the image of the sun onto a paper (charta) affixed to a wooden plank (asserculus ligneus). The paper had been prepared with horizontal and vertical axes, marked regularly so that concentric circles could be constructed from them; and although the three men missed the beginning of the eclipse, they were able to observe most of the rest of the event, drawing directly onto the chart the outline of the eclipsing moon at intervals timed by a portable clock (borologium ambulatorium). They worked for about two and a half hours, missing totality itself as they moved the telescope hurriedly from one window of the observatory to another. Rawlinson later engraved onto brass the observations they had drawn on the paper: the result shows, overlaid, the various snapshots of the moving edge of the moon; and beneath it is a series of smaller circles, representing these different stages now as a sequence. This was published as part of Wallis's description, but Rawlinson signed the engraved plate with his name and role ("Ri: Rawlinson cælavit," "Richard Rawlinson engraved this").

There is some evidence that Rawlinson himself circulated both his own engraving and this section of the book. A copy of the former survives pasted into a different astronomical work now in the library of New College, Oxford; and the royalist astrologer and ordnance officer Thomas Wharton recalled how "that Learned Mathematician (my worthy Friend and Country-man) Mr. Richard Rawlinson Fellow of Queens" sent him the entire printed description. ${ }^{48}$

Fig. 1. Rawlinson's engraving of 1654 Eclipse, from New College, Oxford (BT3.154.9).

Rawlinson was member enough of Wallis's mathematical circle that in 1655 the latter could mention him to William Oughtred, along with Ward, Wren, Lawrence Rooke, and Robert Wood of Lincoln, as those local mathematicians to whom he had posed his problem concerning the quadrature of the circle, part of the process that would lead to Wallis's landmark Arithmetica infinitorum. ${ }^{49}$ Wallis later reported to the intelligencer Henry Oldenburg in London that Rawlinson had been the man, "first, in writing; afterwards, in Print," who had in February 1658 communicated to him a problem set by "Jean de Montfert," probably a pseudonym for Blaise Pascal. ${ }^{50}$

Rawlinson and Wren in turn were friends, and it was Rawlinson who jogged Wren to send to Samuel Hartlib in London his design for a transparent beehive, which 
Hartlib eventually published. ${ }^{51}$ Indeed, in the 1650s Rawlinson became acquainted with both Samuel Hartlib and the scholar John Selden in London, as we learn from surviving letters sent once again by the Principal of Queen's, Gerard Langbaine, to Selden, and from letters addressed to Hartlib by Rawlinson himself. It is to these few but valuable letters that we now turn, as they allow us to fill in several details of Rawlinson's activities both in and before these years.

Langbaine and Selden had been correspondents for several years, Rawlinson (always "Rallingson" in their correspondence) first appearing in their letters on 11 February 1651 amidst a report on manuscript texts of the ancient writers on music. Langbaine and Selden were investigating such texts at this time for the benefit of the precocious Danish scholar Marcus Meibom, whose Amsterdam edition of the Antiqua Musica auctores septem appeared in 1652, greatly assisted by Selden and Langbaine's labours. ${ }^{52}$ Langbaine orchestrated transcription work at Oxford, and in this letter he promised Selden that he had committed some palaeographically difficult sections of a Barocci manuscript of Ptolemy's Harmonica to the care of "a hopefull yong man of this Coll: \& an excellent Mathematician, Mr Rich: Rallingson." ${ }^{, 53}$ (In the event Meibom did not include a text of the Harmonica, however; Wallis's landmark edition, prepared from eleven manuscripts, including MS Barocci 124, presumably the text formerly transcribed by Rawlinson, would appear in Oxford in 1682.) Just over a year later, Rawlinson met Selden, as the bearer of a letter of 4 May 1652. This letter furnishes two significant pieces of information about Rawlinson's own exploits:

The Bearers name is Mr Rallingson, a fellow of our Coll: a very sober civill man, and a hard Student, a good Schollar otherwise, but an excellent Mathematician; he was some yeers with My Lord of Dorchester, and I had much adoe to recover him againe; he is just now informed that his friend Mr Foster, one of the Readers of Gresham Coll: is lately dead, and (if he doe not start too late) intends to try whether he may not be thought fitt to succeed him: his abilityes in those Studyes are very well knowne to all here, \& many others elsewhere ... ${ }^{54}$

Langbaine then implored Selden to use all his interests to secure Rawlinson the professorship. Samuel Foster, whose second spell as Gresham Professor of Astronomy ran from 1641 until his death in this year, was also interested in eclipses, but, despite Selden's indication that he was willing to help Langbaine's candidate if he could ${ }^{55}$ Foster was in the event succeeded in his post by Lawrence Rooke, whom Rawlinson would have known well from the Oxford scene. Rooke, who also lodged at Wadham in this period, was a close ally of Wilkins and especially Ward and Walter Pope, who recalled him in extravagant terms as "the greatest Man in England for solid Learning ... for Dr. Barrow i.e. Isaac Barrow of Cambridge] had not then reachd his Zenith." 56 There were no hard feelings from Rawlinson or Langbaine; as the latter reported to Selden,

... as it is, I am not sorry at all, (for wee shall have more of his Society here) nor himself much; though he missed of the maine, yet he lost nothing by his journey: and upon the whole matter I doubt not but he will acknowledge with me oủ $\delta \dot{\varepsilon}$ oü $\tau \omega \kappa \kappa \tilde{\omega} \varsigma$ [in this way nowise ill]..$^{57}$

Indeed, Langbaine was not the only man who sought to press Rawlinson's case, as there is a letter from William Petty to Hartlib of 17 May 1652 requesting assistance in the same cause. ${ }^{58}$ This in turn probably allows us to place Rawlinson in the circle of experimentalists who met at the lodgings of Petty in Buckley Hall, following Petty's arrival in Oxford in 1650. 
Langbaine's other remark, that Rawlinson had been "some yeers with My Lord of Dorchester," also allows us to adjudicate the problem earlier mentioned concerning his patron at this time. He was, Langbaine now claims, in the service of Henry Pierrepont, Marquess of Dorchester (1607-80), to whom he had presumably been recommended in royalist Oxford, where the scholarly Pierrepont had been a member of the king's Council of War. Langbaine, as we saw, had earlier said that Rawlinson had been with the "Earle of Kensington," technically an impossible title, and I propose that Langbaine erred in his earlier claim, deliberately or otherwise. Henry Pierrepont seems the more secure suggestion, and this is confirmed by some notes in Rawlinson's own mathematical notebooks, on $£ 810$ s received from "the Ld Marquesse of Dorchester" on Christmas Day of 1646, and other actions associated explicitly with Dorchester. ${ }^{59}$ Pierrepont's library was donated to the Royal College of Physicians after his death, where it remains, named for its first owner as the Dorchester Library. It is particularly rich in mathematical books, and still includes many of the publications mentioned in this article.

This brings us to Rawlinson's mathematical notebooks, now Queen's College, MSS 425-32. ${ }^{60}$ These eight small notebooks, in English, are almost entirely unknown, but they are certainly those of Richard Rawlinson, as they contain two pieces of evidence that independently tie them to his biography. The first, on the Marquess of Dorchester, we have already encountered. The second is some notes on a lunar eclipse on the final page of MS 427:

An. 1652. I observed.

March $14^{\circ}$.

beginning of ye [Moon] eclipse at Oxõ $14^{\mathrm{h}} \quad 44^{\prime}$

Great obscuration 16. 18'

The End about $17.45^{\prime}$

Now the content of the manuscripts alone would strongly suggest Rawlinson as a candidate for their authorship; the additional evidence that the scribe was also an eclipse observer in Oxford and under the patronage of Dorchester renders the attribution likely. This may be confirmed by the earliest appearance of these manuscripts in a catalogue, namely the union catalogue of manuscripts in British and Irish libraries, co-ordinated by Edward Bernard in Oxford, and finally appearing in 1698. There, the entry for the library in Queen's is followed by a separate catalogue for the manuscripts in the Taberdars' Library. Here we find four entries for manuscripts treating the Aristotelian corpus by the well-known scholar Richard Crakanthorpe (1568-1624) of Queen's, and after them six entries describing seven volumes of Euclidean material, specifically attributed to Richard Rawlinson, and with shelf marks that can still seen on the volumes today. ${ }^{61}$

The manuscripts are seemingly in two different hands, a larger and a smaller, but these can be shown to be both authorial from the way in which they are seamlessly intertwined; when one hand is obviously adding material later, it is typically the smaller hand, which we also see in the notes entered in endpapers. The current numeration of the manuscripts is not very helpful in explaining their interrelations, and so below I present a reordered description of the series, first in brief, and then in detail in an appendix. The manuscripts in the first column probably precede those in the second. For reasons that will be explained below, they probably date from 1646 and perhaps the two or three years immediately before then.

MS 425 Euclid, Elements, 1-6

MS 428 Euclid, Elements, 7-10

MS 431 Euclid, Elements, 7-10, a copy of MS 428

MS 429 Euclid, Elements, 11-13

URL: http://mc.manuscriptcentral.com/rsev 
MS 430 pseudo-Euclid, Elements, 15, etc. MS 432 Euclid, Data, with other later pieces

MS 426 Theodosius, Sphaerics MS 427 Theodosius, Sphaerics, a copy of MS 426

Thus Rawlinson prepared vernacular digests of Euclid and Theodosius, the two fundamental texts for the trigonometry necessary for the mathematical astronomer, and then reworked his own versions.

That these manuscripts are in English is notable. Although Euclid had of course been available in English since Billingsley's landmark Elizabethan translation (1570), it is unusual to find academic manuscripts of this nature in the vernacular at this date.

Rawlinson then recopied and to an extent rewrote at least two of these four manuscripts, adding also the apocryphal fifteenth book of the Elements, as well as Euclid's Data, and several other Euclidean and later pieces, more fully described in the appendix. The table above also suggests that Rawlinson may well have recopied MSS 425 and 429, as he did 428 and 426, but these, if they existed, have long been lost.

We do not know for sure when these manuscripts reached the Taberdars' Library, nor whether they were directed there by Rawlinson himself or whether another party caused this to happen after his death. That they were to be found specifically in the Taberdars' Library might suggest that Rawlinson deposited them there himself, before he left Oxford; but in that case we would have to assume that the papers in the hands of Carr of All Souls were different and later manuscripts, having somehow made their way back to Oxford, where the existence of these earlier ones had been forgotten, despite their presence in Rawlinson's old college. This seems an increasingly implausible chain of consequences, and the principle of parsimony encourages the conclusion that the Queen's manuscripts are the very manuscripts so sought for after Rawlinson's death and in the hands of Carr of All Souls, containing "nothing ... desirable being but Excerpta from Euclid[,] Herigon and Oughtreds Clavis." This in turn may suggest that Carr is responsible for their current location.

What was the original function of these eight small volumes for Rawlinson? The most likely explanation is that they were tutorial teaching texts, both an opportunity for Rawlinson to systematize and process his own readings in Euclid and Theodosius, and also a practical way of generating textbooks for tutorial instruction. This sense is strengthened by the presence in these manuscripts of several shorter tracts, especially those in MS 430, which concludes with tracts on Mechanics, Optics, Catoptrics, Dioptrics, Perspective, and Algebra. These kinds of "curricular crib" are commonly enough encountered in collections associated with the early modern universities, always small pocket-size manuscripts, usually entitled systema, compendium, epitome, elementa, most commonly in logic, but often running through the entire arts curriculum, including tracts on arithmetic, geometry, astronomy, the use of the sphere, sometimes even epitomes of the newer philosophical schools of Descartes and Gassendi. ${ }^{62}$ My observation of Oxford and Cambridge examples dated across several decades tends to confirm that they were drawn up by college fellows acting as tutors, lent or dictated to students, and often in use over generations and across colleges. ${ }^{63}$ It was a cheap and customised way to structure teaching, and these booklets, along with several printed examples, are perhaps the closest we can come to the early-modern tutorial in action.

Fig. 2. An opening from one of Rawlinson's mathematical compendia (Queen's College MS 430, fols. 68v-69r). The diagrams most likely derive from those in Guidobaldo del Monte's Mechanicorum liber (Pesaro, 1577).

Rawlinson's tracts fit comfortably into this genre both as objects and as textssystematic abbreviations of core texts in pocketbook form. These are certainly not 
commonplace books, therefore, nor notebooks; but neither are they manuscripts worked up for print publication. They exist as they were intended to exist-in an educational economy flexible enough to exploit scribal publication when this made the best financial and pedagogical sense. That Rawlinson worked over these manuscripts, however, does show that these were important texts for him, a project that he was teaching and developing as a young fellow in the mid 1640s. They are certainly much more detailed than most of the surviving analogues in the other arts subjects. In this connection it is perhaps significant that many of the titles of these notebooks, those attributing and identifying the underlying texts, have been erased. It may be that Rawlinson came to see this series as his own cursus mathematicus, and wished to obscure the nevertheless obvious fact that he was in effect offering digests of standard authorities.

Finally, that these texts came to rest in the Taberdars' Library is significant. These were teaching and learning texts specifically for perhaps the brighter young BAs, who were in effect working on their MAs and waiting for fellowships to open up. In short, if my supposition here is correct, it suggests to us something not just about what kind mathematics was taught, but to whom, and at what point. Over two hundred printed books from the Taberdars' Library survive among the modern collection at Queen's, most with donors' names inscribed; a full study of this fascinating library is now possible, and would open an unusually precise window onto a certain educational stage in early modern Oxford.

As for Rawlinson and Samuel Hartlib, they became acquainted perhaps in 1654. The first surviving letter between them dates from 30 January 1654 -i.e. 1655, as Rawlinson always employs Old Style_and was accompanied by some copies of Rawlinson's engraving of the eclipse observations he had made with Wallis (Wren is not mentioned). He writes, too, "I had herewith given you another observation of a Solar ecclipse on Saturday last, (for I was in readines for it) had not the day been cloudy till it was over." This is the eclipse that took place on 6 February 1655, New Style. ${ }^{64}$ The letter is also useful because Rawlinson apologises that he "had not opportunity to waite upon Mr Benlowes before I left London, else I doubted not to haue obtained a copy of the experiments he promised you, and I suppose performed." This is Edward Benlowes the poet and philanthropist, who was also friends with Thomas Barlow of Queen's, and who had recently promised (but seemingly never delivered) Hartlib a $£ 20$ annual grant. ${ }^{65}$

Rawlinson's next surviving letter to Hartlib comes after a gap, and is dated 22 June 1657. In terms of Rawlinson's known networks, it also allows us to add the Aberdonian George Dalgarno to his acquaintance; Dalgarno was at this point a schoolmaster in Oxford, and working on a modification of shorthand that would lead him to formulate his own ideas on an artificial, philosophical language, and into an ultimately disruptive partnership with John Wilkins. ${ }^{66}$ This letter, however, is more significant in that it allows us to identify, date, and recover Rawlinson's only surviving extended work. With the letter Rawlinson enclosed ten copies of another eclipse engraving, this time of the eclipse "which Dr Wallis \& myselfe observed at Oxford 16. Ian: 1655." He apologised for a trivial error made in the engraving, and desired Hartlib to send copies to the continental luminaries Frans van Schooten, Ismaël Boulliau, and Johannes Hevelius himself. Bearing in mind Rawlinson's dating habits, 16 January '1655' is really 16 January 1656, indeed 26 January in the Gregorian calendar-the date of a genuine solar eclipse. So Rawlinson managed to engrave at least two such plates for two different events. He continues:

I haue also engraven a short Trigonometry which I haue had long by me but could not yet get time to publish but I hope I shall ere long, in the interim I haue sent you some papers of them also, which if you please you may send away with 
the eclipses, though they be below such learned men yet possibly they may not be displeased therewith, till my leisure permit somewhat more worthy of their view. I haue sowne up one as you must the other; I pray let me heare from you how they are received by your friends beyond sea.

This engraved work, which I shall call, after Rawlinson's own phrase, his "Short Trigonometry," has been almost entirely forgotten. It has not to my knowledge been mentioned by scholars either of early modern Oxford or of the Hartlib Circle. No such work is currently recognised by the English Short Title Catalogue.

And yet it does survive, seemingly in a sole copy, in the British Library. ${ }^{67}$ Nor has it been entirely overlooked. The historian of mathematical notation Florian Cajori found it in the collections in the early twentieth century, and announced what seemed to him Rawlinson's distinctive contributions to the history of trigonometrical notation: first, the designation of the sides of a triangle by the same letters, respectively, as the angles opposite, the former expressed by A, B, C, and the latter by a, b, c; and secondly, the use of letters rectilinear in form for plane, but curved for spherical, triangles. ${ }^{68}$ As Cajori observed, Rawlinson used many symbols in common with Seth Ward, reflecting their indebtedness to William Oughtred, but Rawlinson appears to have been the first to employ these two specific innovations. The second was not taken up by subsequent practitioners; the first is still taught as standard practice in schools today.

Fig. 3. The first plate of Rawlinson's “Short Trigonometry," from British Library, 530.i.32.(1.) (C British Library Board)

Early modern extbooks on plane and spherical triangles for the beginner commenced with Bartholomäus Pitiscus, Trigonometria (1595, many subsequent editions), which, at the behest of Richard Hakluyt, achieved an English translation in 1614, twice reprinted to 1642. At least six English writers soon published similar textbooks before the Restoration. ${ }^{69}$ Seth Ward and Rawlinson were both directly indebted to William Oughtred: Ward had studied with him in person; and Rawlinson, we saw, wrote a lost commentary on the Clavis mathematica. In the matter of trigonometry, Oughtred himself was a keen reader of Pitiscus, as his surviving copy demonstrates. ${ }^{70}$ In 1652 Ward published on the Oxford press his own short Idea Trigonometria Demonstrate, "In usum Juventutis Oxoniensis" ("For the use of Oxford students"); it was widely used. ${ }^{71}$ Trigonometry in the period was the handmaid of astronomy (and geodesy), especially the trigonometry of spherical triangles. Ward's concise work renders this function explicit: mathematical astronomy, he affirms, depends on the doctrine of triangles, both plane and spherical, and no one without trigonometry is equipped to perform the complex calculations required for mathematical astronomy.

Rawlinson's "Short Trigonometry" is directly derivative of Ward's popular textbook in form, content, and purpose. It consists of an initial page headed "Symbola" followed by eight numbered pages, and two subsidiary diagrams. Preserved with the surviving copy is also Rawlinson's plate for the eclipse of 16 January 1656, and for this reason I shall date the "Short Trigonometry" to c. $1656 .{ }^{72}$

Fig. 4. Rawlinson's second surviving eclipse plate, from British Library, 530.i.32.(1.) (C British Library Board)

Ward commences his Idea Trigonometrice by displaying the two "Fundamenta" for solving right-angled triangles (p. 2); Rawlinson's first plate commences with these two rules too, albeit notated slightly differently. Ward's facing table (p. 3) of seven solutions is paralleled by Rawlinson's seven; and both men accompany this with the same diagram, 
again differing only in notation. Ward then progresses to non-right-angled triangles (pp. 4-5), and again he is effectively mimicked by Rawlinson, who is thus compressing the first four pages of Ward's already telegraphic presentation into one small engraved plate. A similar parallelism obtains for the two men's sections on spherical triangles, although Ward inevitably goes into more detail. Of course both men were not at liberty to innovate significantly, but their almost identical sequencing demonstrates that Rawlinson's "Short Trigonometry" is in effect Ward's Idea abridged and reduced to tabular form, a perhaps supererogatory exercise.

Fig. 5. The second plate of Rawlinson's "Short Trigonometry," from British Library, 530.i.32.(1.) (C) British Library Board)

Rawlinson's remarks to Hartlib suggest that at the date of the letter cited above, he had not yet "published" his "Short Trigonometry," but that he had "some papers of them," which he was sending. Are we to interpret these "papers" as a trial printing of the trigonometrical plates or some close manuscript version? Or are these something slightly different? At any rate, Hartlib soon forwarded some part of Rawlinson's enclosures to the mathematician Nicolas Mercator (1620?-1687), at that point at Petworth, acting as tutor to none other than Joceline Percy; ${ }^{73}$ one wonders whether this was the means by which Rawlinson later became tutor to the same boy. Mercator read what he had received with care, sending comments back to Hartlib in Latin. This must have happened in late June or early July of 1657, for Rawlinson returned his thanks to Hartlib on September 1, in the hands of one "Mr Mursten ... along with a very honourable Gentleman his neighbour Polonian." 74 This "Mursten" is Faustus Morstyn, a Polish nobleman and scholar resident in Oxford at this time, indeed the very man who had asked Dalgarno to comment on a recent shorthand system that had come to his notice, thereby launching Dalgarno on his quest to develop an artificial language. As Rawlinson's letter also makes clear, delivering it was to be Morstyn's opportunity to meet Hartlib for the first time, although in fact the two men had already been in epistolary communication. ${ }^{75}$

As for Rawlinson himself, he wanted to know who his anonymous critic was, but Mercator refused to be drawn on his identity, insisting politely but firmly to Hartlib that he would rather remain "quàm Aristarchi cujusdam, qui nihil ipse cùm facit, tamen aliorum labores carminat" ("as some Aristarchus, who does nothing himself, but hymns the labours of others"). ${ }^{76}$ Rawlinson responded to this detailed criticism in a letter evidently sent with another "litle paper ... formerly engraven":

... as for this $1 / 2 Z-E=1 / 2 X$ which he would haue put in[.] I left it out on purpose, for when I well considered the scheme to me \& to any that did so it seemed sufficiently supplyed by it $\&$ the method of demonstration there used. That I omitted $1 / 2 Z-E=1 / 2 X$ on purpose you may perceive by this litle paper which I had formerly engraven wherein it is expressed thus Quia $Z / 2-E=X / 2$ but I liked not that first way \& therefor cut it as you haue it. For the last figure but one to which the learned Gentleman would haue premised, that in the Analemma Meridians are to be projected into Ovals, I confesse it is to be understood, but I suppose it so knowne to those I intended this method for (especially without the adnotations I haue for it) that I judged it needles, but as your worthy friend sayes it must be premised in that demonstration, yet I haue seen a good Author who in a very like case made noe mention of the same thing. ${ }^{77}$ 
The problem is that this letter appears to be discussing first algebra ( $\mathrm{Z}, \mathrm{E}, \mathrm{X})$, then astronomy (meridians), and not trigonometry; and there is nothing in the surviving "Short Trigonometry" to which these remarks might pertain. So all we can say here is that Hartlib received and Mercator reviewed materials differing from the "Short Trigonometry," and what — indeed if there was any_-reception of the latter there was remains unknown.

Rawlinson thereafter faded out as a correspondent of Hartlib. His last letter, dating from 17 April 1658, answered a call to speed to London with reticence to do so, protesting college business, a theme of his other letters too. ${ }^{78} \mathrm{He}$ will only come if absolutely necessary, to meet certain "worthy persons you name"- but would rather "doe so in Oxford." We do not know if Rawlinson relented and went to see Hartlib; after this letter he disappears from the surviving Hartlib Papers. Indeed after this letter we hear no more of Rawlinson's intellectual interests, other than that fascinating, isolated reference to an observatory in Queen's in 1664. The Restoration brought some successes to Rawlinson: a doctorate, a rural parish, and a well-provided wife whom he may well have found "deare." But it is also the period in which he drifted into obscurity. For Royalist Rawlinson, it was the Civil War and Interregnum that afforded him his memorable years.

Appendix: The Rawlinson Mathematical Notebooks (Queen’s College, MSS 425-32)

N.b. each volume tends to bear at least four previous cancelled alphanumeric shelfmarks, commencing B, D, P, Z, and a final uncancelled one commencing N. Bernard, Catalogi, 2nd pag., 30, lists these under their "P" numbers, from 16 to 22 inclusive. Bernard's list is therefore one short of the eight listed below. Bernard's description under P 18 is obviously copied from the contents description written into the volume marked "P 23," now MS 432; it is really MS 425 that is marked, in its final endpapers, "P 18," being Euclid, Elements 1-6. But "P 23" has been added to MS 432 in a slightly different hand, and MS 425, the real "P 18" was most likely the manuscript temporarily mislaid at the time this first list was compiled.

MS 425 Euclid, Elements, 1-6

$1 \mathrm{r}$, a list of books sought, mainly mathematical texts, but also including what Rawlinson identifies as Thomas Browne's "Error Epidemicus," with several London carrier routes and addresses, possibly where they may be had, including Langbaine at the Hen and Chicken near St Dunstan's. Especially the reference to Browne, published, but with the title evidently not exactly known, would date this list to 1646 .

$1 \mathrm{v}-2 \mathrm{r}$ lists more books, including "Chemicall Bookes."

$2 \mathrm{v}$ bears the later attribution "By Christopher Rawlinson of Queens' College."

4r-101r Euclid 1-6, with the heavily erased heading "First Book of Euclides Elements." The text is in English, with comments by Apollonius, Proclus, Pappus, Peletarius, John Dee,

"Flussates"/ "Flyssas" (i.e. Francois de Foix), "Campane" (i.e. Campanus), these final forms perhaps showing the influence of Billingsley's translation.

$101 \mathrm{v}$ blank.

102r-v further notes and a key for an alphabetic cipher.

MS 428 Euclid, Elements, 7-10

1r-117r, Elements 7-1, commencing with the heading "7. Booke." This has a great number of diagrams tipped in on tiny cut-outs of paper. Among the commentators, "Campane" is the most frequent, but "Montaureus" (i.e. Pierre Mondoré) joins him too. Mathematical notes in endpapers. This is the only volume in the set to be bound in vellum; the rest are in calf.

MS 429 Euclid, Elements, 11-13

The front pastedown contains notes on books, carriers, and on Dorchester as discussed above. The booklist includes Galileo, Discorsi e dimostrazioni matematiche intorno à due nuove scienze attenenti alla mecanica \& i movimenti locali (Leiden, 1638), in Italian, priced at $4 s 7 d$. In the text itself, 
Herigone provides the final scholia, perhaps the source of the later remark that Rawlinson's papers contained material from that author.

1r-98r, Elements, 11-13.

MS 426 Theodosius, Sphaerics

$1 \mathrm{r}-42 \mathrm{v}$, Sphaerics in three books. The attribution is again deleted. $43 \mathrm{r}-46 \mathrm{v}$, on anomaly.

$47 \mathrm{ar}-109 \mathrm{v}$, short, traditional tracts on the "theoriques" of the sun, moon, eclipses of both, of the planets, and then of the passions of the planets, in eight pieces. $71 \mathrm{r}$ is a table for finding the place of the Dragon's Head from 1600 to 1620. One worked example is dated 21 November 1601 (72r). These were probably derived in great part from Thomas Blundeville's Theoriques of the Seven Planets (London, 1602), which indeed includes all these discussions. There are various tipped-in diagrams and tables accompanying these latter tracts.

MS 431 Euclid, Elements, 7-10, a copy of MS 428

1r-86r, Elements, 7-10.

This manuscript repeats the text of MS 428 and was generated from it, including the many inserted diagrams. The text extents match, the latter becoming however more abbreviated. It is marked at the end "An. dm 1646." (85r) This again suggests that this whole set of manuscript should be dated to 1646 and perhaps the years immediately prior to that.

The three final manuscripts below share the same dimensions and binding, and all have internal authorial pagination; they may be considered a subset. Like the manuscripts above, they all bear several cancelled strings of earlier shelfmarks, but these three alone all have a deleted "W 1: 5" in the top left-hand corner of the front pastedown.

MS 430 pseudo-Euclid, Elements, 15, and other pieces. 1r-52r. The title has again been defaced, but p. "73" (1v) is headed "Appendix of the Geometry of Planes," and later pp. "156"(42r) and "166" (49r) are headed as the "15 th Book," showing that this is the spurious final book of Euclid, on solids in solids. The section on planes, from 10r, contains some commentary, from, e.g., Snell. This whole section is authorially paginated from 72 to 172 .

58r-198r. Short tracts on Mechanics, Optics, Catoptrics, Dioptrics, Perspective, and Algebra. Mechanics commences its own pagination, but is preceded (57v) by a list of authors from Aristotle to Galileo, Guevara, Mersenne, and Bettinus, with mentions of Ramelli, Zoncha, Bessonius, Vegetius, and Lipsius, for "Engines." The sections on Optics to Perspective are authorially paginated as one section, pp. 1-136, with some fine illustrations; Algebra is freshly paginated pp. 1-109. The notation is indebted to Oughtred.

MS 432 Euclid, Data, with other later pieces

The first long tract is derived from Euclid again, starting with his "Data" in 15 propositions, i.e. the material that often follows pseudo-Euclid, Book 15. There are a few notes of book titles in the final endpapers. The remainder of this manuscript comprises more recent tracts, the complete contents, following authorial pagination (there is no curatorial foliation), being:

pp. 1-35 Euclid, "Data."

pp. 37-48 Four problems, heading deleted.

pp. 49-54 Apollonius Pergaeus, on the section of proportion, as restored by Snell. (A reference to Wilebrord Snell, Apollonius Batavus (Leiden, 1608).)

pp. 55-63 Apollonius Pergaeus on the geometry of inclinations, as restored by Gethaldus. (A reference to Marinus Ghetaldus, Apollonius Redivivus and Supplementus Apollonii Galli (Venice, 1607, 1613).)

pp. 64-87 Anderson's supplement to the Apollonius Redivivus. (A reference to Alexander Anderson, Supplementum Apollonii Redivivi with an appendix Variorum problematum practice (Paris, 1612).)

pp. 88-104 From Vieta's Apollonius Gallus. (A reference to Franciscus Vieta, Apollonius Gallus (Paris, 1600).)

pp. 105-112 "Of problemes whose construction Regiomontanus saith he knowes not." (Possibly from Clément Cyriaque de Mangin, Problemata duo nobilissima, quorum nec analysin geometricam videntur tenuisse Ioannes Regiomontanus et Petrus Nonius ... nun ... elaborata (Paris, 1616).) 
pp. 113-34 Collection of "divers problemes."

pp. 135-75 "Andersons Practicae of divers problems," ending with a note on Vieta's

pp. 176 Note on Pappus.

pp. 177-231 "The Doctrine of Angular Sections."

pp. [241]-[312] An introductory tract, with fresh pagination from 1 to 71 , on mathematics, explaining definitions, terms, notations, showing the influence of Oughtred again.

MS 427 Theodosius, Sphaerics, a copy of MS 426, followed by Euclid's "Musica" and a tract "De Musica Recent[iora]"

Authorial pagination pp. " 145 "-" 409 ", " 145 " to " 349 " being for Theodosius (i.e. $1 \mathrm{r}-124 \mathrm{v}$ ), and “354"-“409” (i.e. 127r-159v) for the last two tracts, with appended by musical diagrams. In the definitions Theodosius's sixth definition is replaced in this text with that of Clavius, and the same hand has then entered this as an alternative definition for no. 6 in MS 426. This strongly suggests that MS 427 is in its origins a copy of MS 426, which has in turn been marked with some of the revisions to MS 427. Strikingly, the many diagrams throughout the Theodosius text have all been carefully cut from a printed edition, evidently in French. This is almost certainly Hérigon's parallel-language Cursus Mathematicus (Paris, 1634-37; $2^{\text {nd }}$ ed. 1644).

\section{Notes}

I am grateful to Philip Beeley, Mordechai Feingold, Yelda Nasifoglu, and Benjamin Wardhaugh for comments on a draft of this article.

${ }^{1}$ [Ward and Wilkins], Vindiciae Academiarum, 29.

2 Feingold, Mathematician's Apprenticeship; idem, "Mathematical Sciences and New Philosophies."

${ }^{3}$ Nicolson and Burn, History and Antiquities of the Counties of Westmorland and Cumberland, 1:197-99; Farrer, Records Relating to the Barony of Kendale, 2:157-62.

${ }^{4}$ Farrer, Records Relating to the Barony of Kendale, 3:222-33 (Palatinate payments); Binham, The Church at Heversham, 36-7 (Calvert and Wakefield); $A C A D$, s.n. "Wakefield, James" (which erroneously has Wakefield as "vicar").

${ }^{5}$ Foster, Alumni Oxonienses, s.n. "Hudson, Richard."

${ }^{6}$ In 1571, for instance, the college had set up a scholarship scheme with the school in Appleby; and from 1613/14 similar scholarships were set up for Kendal school (documents calendared in Archives of the Queen's College, Oxford, 3:45-54). See further Magrath, The Queen's College, 1:33, for statutory regional favouritism.

${ }^{7}$ Documents calendared in Arcbives of the Queen's College, Oxford, 3:99.

${ }^{8}$ Magrath, The Queen's College, 2:260, 264-65; Morgan, "“Books for the yongeur [sic] sort'," 120; Tyacke, ed., HUO, 17, 676. The Clavius edition of Euclid is the Frankfurt, fourth edition of 1654 in two volumes, with Ellis's inscription ('olim socius'), dated 1669 (40a.A.14-15). A second copy of this edition (40a.A.18-19) was presented to the same library by Stephen Green, BA 1707, MA 1710. The earliest list we have for this library dates from around 1725 (Queen's College Library, MS 611). For Ellis, who was nurtured and protected at Queen's by the formidable quartet of Thomas Barlow, Thomas Tully, Gerard Langbaine, and Robert Southwell, see ODNB, article by Ian Green, and the biographical account before his posthumous Three Discourses.

${ }^{9}$ The earliest catalogue is from 1663 (Morgan, Oxford Libraries Outside the Bodleian, s.n. Queen's).

Langbaine's contemporary list of the college's manuscripts is Bodleian, MS Langbaine 7, pp. 411-22.

Rawlinson does not seem to have been a donor to the college library, at least according to the lists in Bodleian, MS Gough Oxon. 15, printed in Macgrath, Queen's, 2:267-78. The college also holds a copy of the two-volume 1607 Frankfurt edition of Euclid (once chained, unlike the Taberdars' books), with its original inscription mostly torn away, but tantalizingly commencing ' $\mathrm{R}$... e Coll ...' in a hand of the time of Rawlinson (40a.A.20-1).

${ }^{10}$ Wood, History and Antiquities, 2:462 (April 1643), being Wood's original English text, but first published in the Latin text, Historia et Antiquitates, 1:359, no material differences. The information is repeated by Wood in the Fasti, 2: col. 60, this time quoting from the original register (see below).

${ }^{11}$ Wood's annotation is "In S, p. 37" = Oxford University Archives, NEP/supra/Reg. Sb, p. 37, also reported in HUO, 718 .

${ }^{12}$ Bodleian, Wood 430 is Wood's annotated copy: see between 1:362 and 363. 
${ }^{13}$ Wood, Fasti, 2: col. 32.

14 Varley, Siege of Oxford, 109-11; Lattey et al:; Victoria County History (Oxfordshire), 4:303-4. For de Gomme and Oxford there is now Saunders, Fortress Builder, 70-3. Ironically, the Provost and Scholars of Queen's subsequently felt they had to complain to Glemham about their unreasonable share of work in labouring on the fortifications (their petition is Queen's College Archives [hereafter QCA] 2 V 108, and there are several receipts of payments for the fortifications, and for casual labourers, at QCA 2 PHI 7 (1)-(13)).

${ }^{15}$ For the Bodleian holdings see the appendix to Marr, “'Curious and Useful Buildings", 130-41, passim. Any one of these might have served Rawlinson's needs, but two immediate examples are Theti's 1589 manual, or Perret's of 1602.

${ }^{16}$ QCA, LR C and D cover the period of Rawlinson's fellowship; LR E confirms his absence from the accounts from the year 1666-67.

${ }^{17}$ The text of the dispensation is given by Magrath, Queen's, 268, n. 1, and see CCEd, both events from Oxford County Record Office, Oxford Diocesan Papers e. 13. For Skinner's ordinations see ODNB, article by Vivienne Larminie.

18 "Rich. Rawlinson Artium magistro et Collegii socio per prepositum et scholares indultum est ut salvis sibi societatis juribus et beneficiis per annum insequentem a Collegio abesse poterit, et ulterius (necessitate illâ Praeposito et scholaribus indicatâ prius et approbatâ) si necesse fuerit" (Magrath, Queen's, 2:8, from QCA, Register H, p. 95).

${ }_{19}$ Burrows, ed., Register of the Visitors.

${ }^{20}$ Magrath, Queen's, 1:267-68, 2:29; Boas, ed., Diary of Thomas Crosfield, 96.

${ }^{21}$ Wood, Life and Times, 1:256; Haugen, "Imagined Universities," 16; ODNB, s.n. "Addison, Lancelot," article by Alastair Hamilton; Bulman, Anglican Enlightenment, 21, 23.

22 Langbaine to Milles, 9 October 1648, QCA 2 T 97. Apart from the indicated strike-through, there is a deleted phrase after "Kensington," and the annotation "absent" and "out of distance" against the entry.

${ }^{23}$ For a survey of such activities at Queen's see Gunther, ed., Early Science in Oxford, 11:123-34.

${ }^{24}$ Frank, Harvey and the Oxford Physiologists, 51, 52, 86-7.

${ }^{25}$ Bodleian, MS Wood donat. 1 (Langbaine's Adversaria, vol. 1), pp. 1-3.

${ }^{26}$ His Oxford predecessor, from whom he may have taken his hint, was Richard Haydocke (1569/70-c.

1642) of New College, engraver, physician, and translator of Lomazzo; some of his characteristic monumental engraving survives in Queen's College chapel, where Rawlinson must have seen it (see Magrath, Queen's, 1:239-40).

27 Wood, Fasti, 2: col. 257. <>

${ }_{28}$ Birch, History of the Royal Society of London, 1:8, 12.

${ }^{29}$ Wood, Fasti, 2: col. 257.

${ }^{30}$ Wood, Fasti, 2: cols. 252-53.

${ }^{31}$ Wood repeated this in Life and Times, 2:183.

32 CCEd, under person ID 165978.

${ }^{33}$ QCA LR D, sub anno. This observatory was first mentioned by Magrath, who misdated its construction to 1664 .

${ }^{34}$ Book of the Valuations, 321.

${ }^{35}$ Foster, London Marriage Licences, col. 1116, certificate issued from St James, Clerkenwell.

${ }^{36}$ PRO, PROB 11/327, fols. 308v-9r. There was a Queensman of this name, BA 1663, MA 1666; he may have been related to Thomas, son of Gilbert Nicholson of Poulton, who matriculated at Christ Church in 1682.

${ }^{37}$ That the marriage licence was issued for Rawlinson and a Mrs Bridget Crooke or Croke, spinster, of Chequers, co. Bucks, confirms the connection; but this Bridget is not recorded in Burke, Genealogical and Heraldic History, 1:354-59. We would expect her to be, perhaps, a daughter of Sir Henry and his wife Bridget Croke, through whom Henry acquired Chequers, but he died in 1659, leaving an only son (357), whereas the licence of 1661 is stated to have been given with paternal consent. We might guess that Bridget was therefore a daughter of this only son, Sir Robert Croke, knight of Chequers, but who predeceased her father, and so is not among his three named surviving daughters, Susan, Mary, and Isabell. This is confirmed by Rawlinson's will, where he talks of "Sir Robert and my lady Croke" as his father- and mother-in-law.

${ }^{38}$ Wallis Correspondence, 3:9, 17.

${ }^{39}$ Rigaud, ed., Correspondence of Scientific Men, 1:151-52, letter of January or February 1671, as inferred by Stedall, Discourse Concerning Algebra, 235, n. 51.

${ }^{40}$ Rigaud, ed., Correspondence of Scientific Men, 1:153-54; Stedall, Discourse Concerning Algebra, 74, 235, n. 51. ${ }^{41}$ A William Iles appears in the imprint of Faerooe, \& Faeroa reserata of 1676; I can find no other certain mention of an Isles or Iles in the booktrade in this period, apart from an annotation dated to 1673 on two Oxford musical manuscripts of the period to the effect that "William Iles" was sending ten manuscript 
books of music to John Fell of Christ Church "for the publick musick scoole"; this may be the same man (Ashbee, Harmonious Musick of John Jenkins, 154-55, discussing Bodleian, MSS Mus. Sch. D.245-7 and F.757). For Anderson and Streete see ODNB, articles by Ruth Rhynas Brown and Patrick Curry. 42 Rigaud, ed., Correspondence of Scientific Men, 1:176 $=$ Wallis Correspondence, 3:543, text from latter. For Carr see Wood, Fasti, 2: col. 327 and Foster, Alumni Oxonienses, s.n.; although his MA was from All Souls, Carr had previously been at Queen's, matriculating in 1660, possibly the connection between him and Rawlinson. Had Rawlinson been his tutor?

43 Bodleian, MS Rawlinson D 862, fol. 168r.

${ }^{44}$ Robinson, "Unpublished Letter," 70; HUO, 383; Poole, Wadham College Books, 46, citing Oxford University Archives, UD 31/1/1, fol. 23r.

${ }_{45}$ Pope, Life, 23-27.

${ }^{46}$ Pope, Life, 31-2.

${ }^{47}$ Wallis, Operum mathematicorum pars altera, part IV, "Eclipsis Solaris Oxonii Visæ ... Observatio."

${ }^{48}$ For the former, one has been found pasted into the front of a copy of Giovanni Battista Riccioli's Almagestum novum of 1653, now New College, Oxford (BT3.154.9). This specific volume arrived in the library in probably 1699 with many other astronomical books from Richard Bestwick, who had, so the library's Benefactors Register (150) claims, been a chaplain of the college; Bestwick had taken his MA from New College in 1666, although he was otherwise associated with Exeter College. For the latter, see Wharton, Hemerologium, 9; Capp, English Almanacs 1500-1800, 188. Wharton and Rawlinson probably met in the 1640s in Oxford, where the former was employed as gentleman clerk of the ordnance office. When the plate for 2 August 1654 appeared in John Wallis's Opera mathematica, I, [487], the original plate had been lost, as it was there reengraved by Michael Burghers.

${ }^{49}$ Letter of Wallis to William Oughtred, 19 July 1655, printed before Wallis, Arithmetica Infinitorum, sig. $\mathrm{Bb} 1 \mathrm{v}=$ Wallis Correspondence, 1:156; the mathematical context is explained by Stedall, Discourse concerning Algebra, 168, and in her edition of the Arithmetica Infinitorum, xvii-xxi. See also Malcolm and Stedall, Jobn Pell (1611-1685), 297-98.

${ }^{50}$ Wallis to Oldenburg, 30 March 1668, in Wallis Correspondence, 2:449, quoting and explaining his earlier published account in the Commercium Epistolicum, 171-72: the "amicorum non nemo cui forte occurebam sero vesperi" ("not the least of my friends, with whom I chanced to meet late last night") is now identified as "Dr. Rawlinson."

51 The Hartlib Papers [hereafter HP], 25/9/1A; Hartlib, Reformed Commonwealth Of Bees, 50; Webster, Great Instauration, 163.

52 Toomer, John Selden, 592-93. Meibom's presentation copy of his edition to Selden is Bodleian, $4^{\circ}$ M 32, 33 Art.Seld.

${ }^{53}$ Bodleian, MS Selden supra 109, fol. 385r.

${ }^{54}$ MS Selden supra 109, fol. 403br.

${ }^{55}$ MS Selden supra 109, fol. 404r, Langbaine to Selden, 2 June 1652.

${ }^{56}$ Pope, Life, 111.

${ }^{57}$ MS Selden supra 109, fol. 374r, Langbaine to Selden, 6 August 1652.

${ }^{58}$ Yale, MS Osborn 64/3, 17 May 1652, cited by Webster, Great Instauration, 155.

${ }^{59}$ Queen's College, MS 429, front pastedown. Also recorded is "Lent Mr Porter for my Lords use 20s Jan: 18. 1646"; and on the facing page there is an account of how Dorchester had asked the writer in his presence to take down, for the purpose of Compounding, a "particular" of the estates in Dorchester's mother's ownership which her son stood to inherit.

${ }^{60}$ They are catalogued solely in the Catalogue of Manuscripts Acquired ... since the publication of $\mathrm{H}$.

O. Coxe's Catalogue. There they are described merely as "notebooks on geometry", and the attribution to Christopher [sic] Rawlinson of Queen's, made in a later hand probably of the eighteenth century, in MS 425, is recorded and rejected. This attribution to Christopher, the noted Saxonist, is indeed impossible, as Christopher only matriculated in 1695; but this early annotator was half-right.

${ }^{61}$ Bernard, Catalogi, $2^{\text {nd }}$ pag., 30. The volume omitted is the one marked P 23.

${ }^{62}$ Feingold, "The Humanities," in HUO, 293-4, 296; E. J. Ashworth, introduction to Sanderson, Logica artis compendium, where several such logical MSS are mentioned.

${ }^{63}$ Their number is legion, but examination of, e.g., Bodleian, MSS Add. A 65, Eng. e. 2312, Rawlinson D 1224, Rawlinson D 1442; Lincoln College, MS Lat. 104; New College, MS 393, will confirm my statements about the interrelations of these texts across time and college.

${ }^{64}$ These and other eclipse datings have been checked against NASA's "Five Millennium Catalog of Solar Eclipse," at https://eclipse.gsfc.nasa.gov/SEcat5/SE1601-1700.html

${ }^{65}$ Hartlib's Ephemerides, for mid-1654 (HP, 28/4/20B). Hartlib also commented "Hee brought mee also acquainted with his Niece that is brought vp in all manner of knowledge and languages. but explained that shee and her mother could not bee draw'n from Popery"- - this niece is probably Philippa, wife of Walter 
Blount; they lived in Mapledurham, Oxfordshire (ODNB, s.n. "Benlowes, Edward," article by P. G. Stanwood). Benlowes presented Thomas Barlow with a personalized copy of his bibliographically remarkable Theophila (1652); it is now Queen's College, PP.r.5, copy 2. For Barlow's books, see Poole, "Barlow's Books."

${ }^{66} \mathrm{HP}, 10 / 9 / 2 \mathrm{~A}-\mathrm{B}$ ("I thanke you also very kindly for your remembrance of me in your late letter to Mr Del Garno"). See further Cram and Maat, George Dalgarno on Universal Language; and Lewis, Language, Mind and Nature.

${ }^{67}$ British Library, 530.i.32.(1.). It can be shown to come from among one of that library's founding collections, namely the library of Sir Hans Sloane, as it bears the telltale Sloane alphanumeric accession code, here "G 531." It is one of five Sloane books traced so far with this accession code, but none is signed by a prior owner. We might note, however, that of the many books of Robert Hooke acquired by Sloane at the posthumous auction of the former's books in 1703 , seven traced so far bear alphanumerics falling between G 371 and G 527. Sloane's books bearing accession codes G 1-546 are listed in vol. 3 of Sloane's accession catalogue (British Library, MS Sloane 3972C), covering the period 1701 to 1707, the nine titles with G 531 being listed on fol. 100r. This opens up the tentative possibility that Sloane acquired Rawlinson's Short Geometry from Hooke's library, although it is not listed under any plausible title in the auction catalogue of his library, the Bibliotheca Hookiana of 1703, and none of the other books in this (otherwise mainly continental vernacular) batch can certainly be located by title among Hooke's collection. Hooke, we also recall, was one of Seth Ward's pupils at this time (Richard Waller, "Life of Dr. Robert Hooke," prefaced to Hooke, Posthumous Works, iv, viii). At any rate, Sloane must have acquired this pamphlet at roughly this time, i.e. 1703. I am grateful to Alison Walker for discussion of this matter. See respectively http://www.bl.uk/catalogues/sloane/ and http://www.hookesbooks.com/hookes-booksdatabase/.

${ }^{68}$ Cajori, "On the History of a Notation in Trigonometry," developed in his History of Mathematical Notation, 1:208-9, 2:116, 162-63, and see 2:142-79 for the wider history of trigonometric notations and terms. Cajori presumably learnt of the little volume by browsing through the British Museum's 1817 printed catalogue. ${ }^{69}$ Apart from Ward and Rawlinson, there are Richard Norwood's Trigonometrie (1631, six editions to 1661), Henry Gellibrand's Institution Trigonometricall (1635 and 1652), William Oughtred's Trigonometria (1657), and John Newton's Trigonometria Britanica (1658).

${ }^{70}$ John Aubrey later attested: "I myselfe have his [i.e. Oughtred's] Pitiscus, embellished with his excellent marginall notes, which I esteeme a great rarity" (Bodleian, MS Aubrey 6, fol. 43r). This is the 1612 Frankfurt edition and is now in the library of Worcester College, Oxford, among Aubrey's other mathematical books presented to that society.

${ }^{71}$ Notable association copies include those of Elias Ashmole (Bodleian, Ashm. 122), John Aubrey (Ashm. 1070(12)), and Robert Hooke (in the Yale Medical Historical Library).

72 One can see that Rawlinson's apology to Hartlib for "some errour in figureing the limbe of the great circle" refers to the fact that Rawlinson forgot to engrave the numbering ("figureing") of the main circle in reverse, so it has printed in mirror image.

${ }^{73}$ ODNB, "Mercator, Nicolaus," by Christoph J. Scriba.

${ }^{74} \mathrm{HP}, 10 / 9 / 3 \mathrm{~A}-4 \mathrm{~B}$; Rawlinson thanks Hartlib for his letter of 15 July.

${ }^{75}$ For Morstyn see Wood, Fasti, 2: col. 197, and for his role in introducing Dalgarno and his schemes to Hartlib see Cram and Maat, George Dalgarno on Universal Language, 10-14, and Lewis, Language, Mind and Nature, 85, 86, 90.

${ }^{76} \mathrm{HP}, 56 / 1 / 74 \mathrm{~A}-75 \mathrm{~B}$, Mercator to Hartlib, 15 September 1657.

${ }^{77} \mathrm{HP}, 10 / 9 / 3 \mathrm{~A}-\mathrm{B}$.

${ }^{78} \mathrm{HP}, 10 / 9 / 5 \mathrm{~A}-6 \mathrm{~B}$.

\section{Bibliography}

Reference works and databases cited by abbreviation

CCEd Clergy of the Church of England Database 1540-1835, consulted online through www.theclergydatabase.org.uk/

ODNB Oxford Dictionary of National Biography. Oxford: Oxford University Press, 2004. Consulted online through www.odnb.com

HP The Hartlib Papers. Sheffield: HRI Online Publications, 2013. Consulted online through www.hrionline.ac.uk/hartlib/

Electronic Databases not listed above

NASA, "Five Millennium Catalog of Solar Eclipse." 
Sloane Printed Book Project

Hooke's Books

\section{Manuscripts}

London

British Library

MS Sloane 3972C

Public Record Office

PRO, PROB 11/327, fols. 308v-9r. Will of Richard Rawlinson

Oxford

Bodleian Library

MS Add. A 65

MS Aubrey 6

MS Eng. e. 2312

MS Langbaine 7

MS Gough Oxon. 15

MS Rawlinson D 862

MS Rawlinson D 1224

MS Rawlinson D 1442

MS Wood donat. 1

Lincoln College

MS Lat. 104

New College

BT1.4.6 (= NCA 3582)

MS 393

Oxford County Record Office

Oxford Diocesan Papers e. 13.

Oxford University Archives

NEP/supra/Reg. Sb

UD $31 / 1 / 1$

Queen's College Archives

LR C, D, E, H

2 T 97

$2 \mathrm{~V} 108$

2 PHI 7 (1)-(13)

Queen's College Library

MS 425-32

MS 611

Yale University, Beinecke Library

MS Osborn 64/3

Provenanced Books

Bodleian

4o M 32, 33 Art.Seld.

Ashm. 122

Ashm. 1070(12)

Wood 430

New College
https://eclipse.gsfc.nasa.gov/SEcat5/SE1601-1700.html www.bl.uk/catalogues/sloane/

www.hookesbooks.com/hookes-books-database/

Part of Hans Sloane's library catalogue

Humphrey Hody, 'Systema Logicæ', 1677

Part of John Aubrey's Brief Lives

Edward Filmer, curricular cribs, 1700

Library catalogues, including of Queen's MSS

Includes lists of donors to Queen's College library

Rawlinson genealogical papers

Humphrey Hody, curricular cribs, 1676

Charles King, curricular cribs, 1681

Gerard Langbaine's Adversaria, vol. 1

Anonymous curricular cribs of $1676 / 77$

Library Benefaction Book, 1616

John Kent, curricular cribs, 1673

Subscription book, 1629-46

Register of Convocation, 1642-47

Accounts of the Savilian Chest, seventeenth-eighteenth centuries

College accounts and registers

Langbaine to Milles, 9 October 1648

Petition of Queen's to Sir Thomas Glemham

Bills for civil war works

Rawlinson's Mathematical Notebooks

Catalogue of the Taberdars' Library, c. 1725

Letter of William Petty to Samuel Hartlib, 17 May 1652

Selden's presentation copy of Marcus Meibom's Antiqua Musice auctores septem (1652)

Elias Ashmole's copy of Seth Ward, Idea Trigonometric (1652)

John Aubrey's copy of Seth Ward, Idea Trigonometria (1652)

Anthony Wood's copy of his Historia et Antiquitates (1674) 
Richard Bestwick's copy of Giovanni Battista Riccioli’s Almagestum novum (1653), with a Rawlinson eclipse plate

Queen's College

40a.A.20-1

40a.A.14-15

40a.A.18-19

PP.r.5, copy 2

Yale

Medical Historical Library, call no. 17th cent
The 1607 Frankfurt edition of Euclid's Elements, presented to the Taberdars' Library by 'R ... e Coll ...'

The 1654 Frankfurt edition of Euclid's Elements, presented to the Taberdars' Library by Clement Ellis

Another copy of the same edition, presented to the Taberdars' Library by Stephen Green

Edward Benlowes's Theophilia (1652), presentation copy to Thomas Barlow

Robert Hooke's copy of Seth Ward, Idea Trigonometria (1652)

\section{Printed Books}

Primary

[Anon.] A Book of the Valuations of All the Ecclesiasticall Preferments in England and Wales London: s.n., 1680. Bernard, Edward, ed. Catalogi manuscriptorum Anglia et Hibernia. Oxford: at the Theatre, "1697" [1698]. Crosfield, Thomas. The Diary of Thomas Crosfield. Ed. F. S. Boas. London: Oxford University Press, 1935. Dalgarno, George. George Dalgarno on Universal Language. Ed. David Cram and Jaap Maat. Oxford: Oxford University Press, 2001.

Ellis, Clement. Three Discourses. London: William Rogers, 1704.

Euclid. Elementorum libri XV. 2 vols. Frankfurt: Jonas Rhodius, 1607.

Euclid. Elementorum libri XV. 2 vols. Frankfurt: the heirs of Jonas Rosa, 1654.

Guidobaldo del Monte. Mechanicorum liber. Pesaro: Hieronymus Concordia, 1577.

Hartlib, Samuel. The Reformed Commonwealth Of Bees. London: Giles Calvert, 1655.

[Hooke, Robert.] Bibliotheca Hookiana. London, s.n. 1703.

Hooke, Robert. Posthumous Works. Ed. Richard Waller. London: Samuel Smith and Benjamin Walford for the editor, 1705.

Oughtred, William. Arithmetica in numeris et speciebus institutio [Clavis Mathematica]. London: Thomas Harper, 1631. [Five revised Latin editions to 1693; English translations of 1647, 1694, etc.]

Pitiscus, Bartholomäus. Trigonometry, or the Doctrine of Triangles. Tr. Ralph Handson. London: John Tappe, 1614.

Pope, Walter. Life of ... Seth, Lord Bishop of Salisbury. London: William Keblewhite, 1697.

Rawlinson, Richard. ["Short Trigonometry."] [Oxford]: engraved by the author. Unique copy: 530.i.32.(1.)

Riccioli, Giovanni Battista. Almagestum novum. Frankfurt: Joannes Beyer, 1653.

Sanderson, Robert. Logica artis compendium. Ed. E. J. Ashworth. Bologna: Editrice CLUEB, 1985.

Wallis, John. Arithmetica Infinitorum. Oxford: Octavian Pulleyn, 1656.

Wallis, John. Operum mathematicorum pars altera. Oxford: Octavian Pulleyn, 1656.

Wallis, John. Commercium Epistolicum. Oxford: Thomas Robinson, 1658.

Wallis, John. Opera mathematica. 3 vols. Oxford: Sheldonian Theatre, 1695-99.

Wallis, John. The Correspondence of John Wallis [Wallis Correspondence]. Ed. Philip Beeley and Christoph J.

Scriba. 4 vols. to date. Oxford: Oxford University Press, 2003-

Wallis, John. Arithmetica Infinitorum. Ed. Jacqueline A. Stedall. New York: Springer, 2004.

[Ward, Seth and John Wilkins]. Vindiciae Academiarum. Oxford: Thomas Robinson, 1654.

Wharton, Thomas. Hemerologium. London: John Grismond, 1656 [recte 1655].

Wood, Anthony. Historia et Antiquitates Univ. Oxon. Oxford: at the Theater, 1674.

Wood, Anthony. History and Antiquities of the University of Oxford. Ed. John Gutch. 2 vols. in 3. Oxford: for the editor, 1786-96.

Wood, Anthony. Athena Oxonienses, with the Fasti Oxonienses. Ed. Philip Bliss. 4 vols. London: Rivington et al., 1813.

Wood, Anthony. Life and Times. Ed. Andrew Clark. 5 vols. Oxford: Oxford Historical Society, 1891-1900.

\section{Secondary:}

[Anon.] Archives of the Queen's College, Oxford. 3 vols. Oxford, 1959, typescript.

[Anon.] Catalogue of Manuscripts Acquired by The Queen's College Oxford since the publication of $H$.

O. Coxe's Catalogue of Oxford college MSS., 1852. [Oxford], 1970, typescript. 
Ashbee, Andrew. The Harmonious Musick of Jobn Jenkins. [Surbiton]: Toccata Press, 1992.

Binham, Roger K. The Church at Heversham. Milnthorpe: for the author, 1984.

Birch, Thomas. The History of the Royal Society of London, 4 vols. London: A. Millar, 1756-57.

Bulman, William J. Anglican Enlightenment: Orientalism, religion and politics in England and its empire, 1648-1715. Cambridge: Cambridge University Press, 2015.

Burke, John. A Genealogical and Heraldic History of the Commoners of Great Britain. Vol. 1. London: Henry Colburn, 1834.

Burrows, Montagu, ed. The Register of the Visitors of the University of Oxford, from A.D. 1647 to A.D. 1658. London: Camden Society, 1881.

Cajori, Florian. "On the History of a Notation in Trigonometry." Nature 2363 (11 February 1915): 642-43. Cajori, Florian. History of Mathematical Notation. 2 vols. Illinois, 1928-29, repr. New York: Dover, 1993.

Capp, Bernard. English Almanacs 1500-1800: Astrology and the Popular Press. Ithaca, NY: Cornell University Press, 1979.

Farrer, William. Records Relating to the Barony of Kendale. Ed. John F. Curwen. 3 vols. Kendal: Titus Wilson and Son, 1926 [repr. 1998].

Feingold, Mordechai. The Mathematician's Apprenticeship: Science, Universities and Society 1560-1640. Cambridge: Cambridge University Press, 1984.

Feingold, Mordechai. "Mathematical Sciences and New Philosophies." In Tyacke, ed., The History of the University of Oxford. Volume IV, pp. 359-448.

Foster, Joseph. London Marriage Licences, 1521-1869. London: Bernard Quaritch, 1887.

Foster, Joseph. Alumni Oxonienses 1500-1714. 4 vols. Oxford, 1891-2.

Frank, R. G. Harvey and the Oxford Physiologists. Berkeley: University of California Press, 1980.

Gunther, R. T., ed. Early Science in Oxford. 15 vols. Oxford: for the editor, 1923-67.

Haugen, Kristine. "Imagined Universities: Public Insult and the Terrae Filius in Early Modern Oxford." History of Universities 16 (2001): 1-31.

Lattey, R. T., E. J. S. Parsons, and I. G. Philip. "A Contemporary Map of the Defences of Oxford in 1644." Oxoniensia 1 (1936): 161-72 [with further notes by Varley and Lattey in Oxoniensia 3 (1938): 75-77]. Lewis, Rhodri. Language, Mind and Nature: Artificial Languages in England from Bacon to Locke Cambridge: Cambridge University Press, 2007.

Magrath, J. R. The Queen's College. 2 vols. Oxford: Clarendon Press, 1921.

Malcolm, Noel, and Jacqueline A. Stedall. John Pell (1611-1685) and his Correspondence with Sir Charles Cavendish: The mental world of an early modern mathematician. Oxford: Oxford University Press, 2005.

Marr, Alexander. "“Curious and Useful Buildings': The Mathematical Model of Sir Clement Edmondes." Bodleian Library Record 18 (2003): 108-50.

Morgan, Paul. "'Books for the yongeur [sic] sort': Oxford Undergraduates and their Books from Stuart to Modern Times." Antiquarian Book Monthly Review 3 (1976): 116-23.

Morgan, Paul. Oxford Libraries Outside the Bodleian. $2^{\text {nd }}$ ed. Oxford: Oxford Bibliographical Society, 1980.

Nicolson, Joseph, and Richard Burn. The History and Antiquities of the Counties of Westmorland and Cumberland. 2 vols. London: W. Strahan and T. Cadell, 1777.

Poole, William. Wadham College Books in the Age of John Wilkins. Oxford: Wadham College, 2014.

Poole, William. "Barlow's Books: Prolegomena for the study of the library of Thomas Barlow (1608/991).” Bodleian Library Record 30 (2017): 13-46.

Rigaud, Stephen, ed. Correspondence of Scientific Men of the Seventeenth Century. 2 vols. Oxford: Oxford University Press, 1841.

Robinson, H. W. "An Unpublished Letter of Dr Seth Ward relating to the early meetings of the Oxford Philosophical Society.' Notes and Records of the Royal Society of London 7 (1949): 68-70.

Saunders, Andrew. Fortress Builder: Bernard de Gomme, Charles II's Military Engineer. Exeter: Exeter University Press, 2004.

Stedall, Jacqueline A. A Discourse Concerning Algebra: English Algebra to 1685. Oxford: Oxford University Press, 2002.

Toomer, G. J. John Selden: A Life in Scholarship. Oxford: Oxford University Press, 2009.

Tyacke, Nicholas, ed. The History of the University of Oxford, Vol. IV. The Seventeenth Century [HUO]. Oxford: Clarendon Press, 1997.

Varley, Frederick John. The Siege of Oxford. London: Oxford University Press, 1932.

Webster, Charles. The Great Instauration: Science, Medicine and Reform, 1626-1660. $2^{\text {nd }}$ ed. Bern and Oxford: Peter Lang, 2002. 


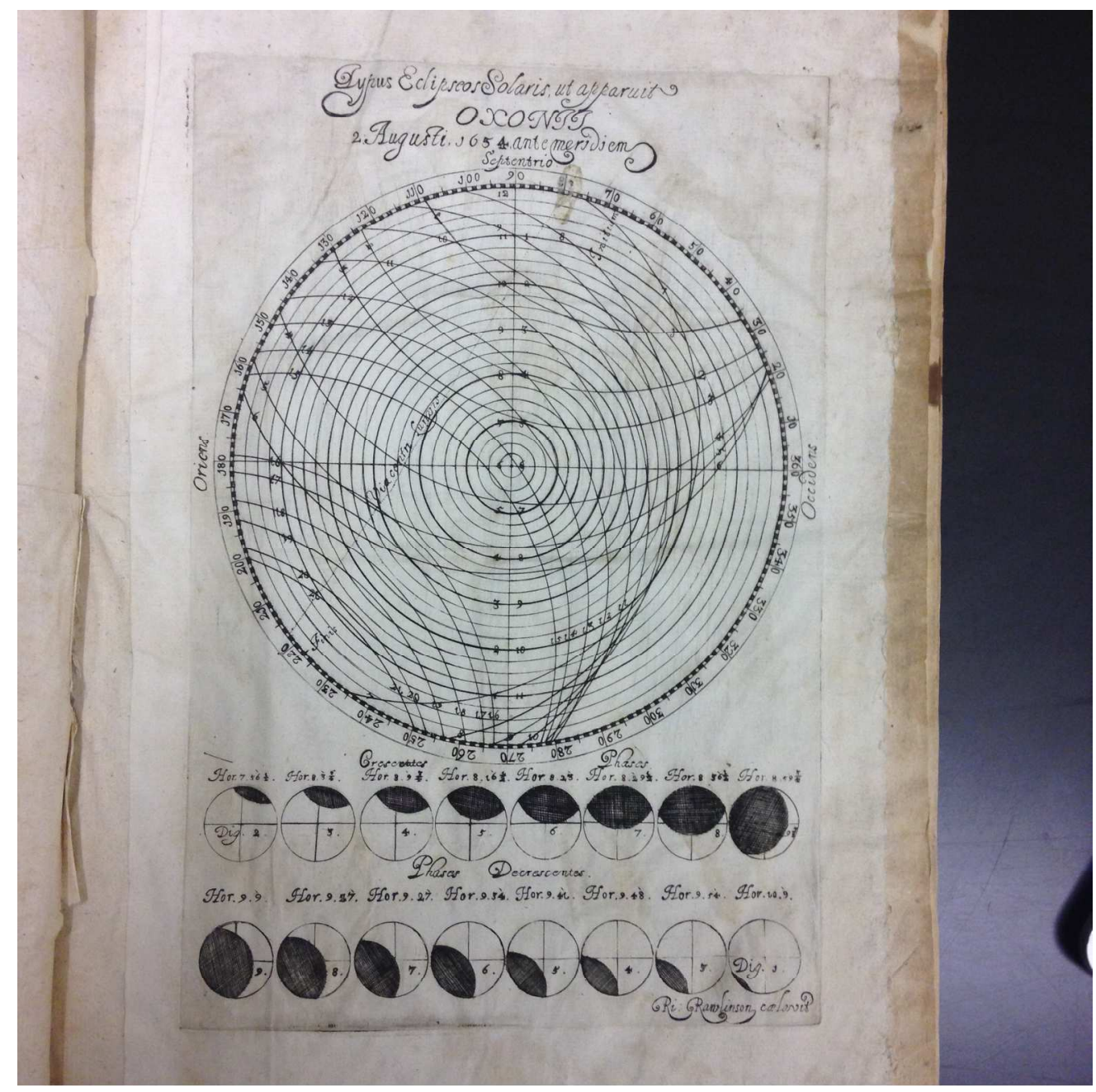

Rawlinson's engraving of the 1654 Eclipse, from New College, Oxford (BT3.154.9). $863 \times 863 \mathrm{~mm}(72 \times 72$ DPI $)$ 


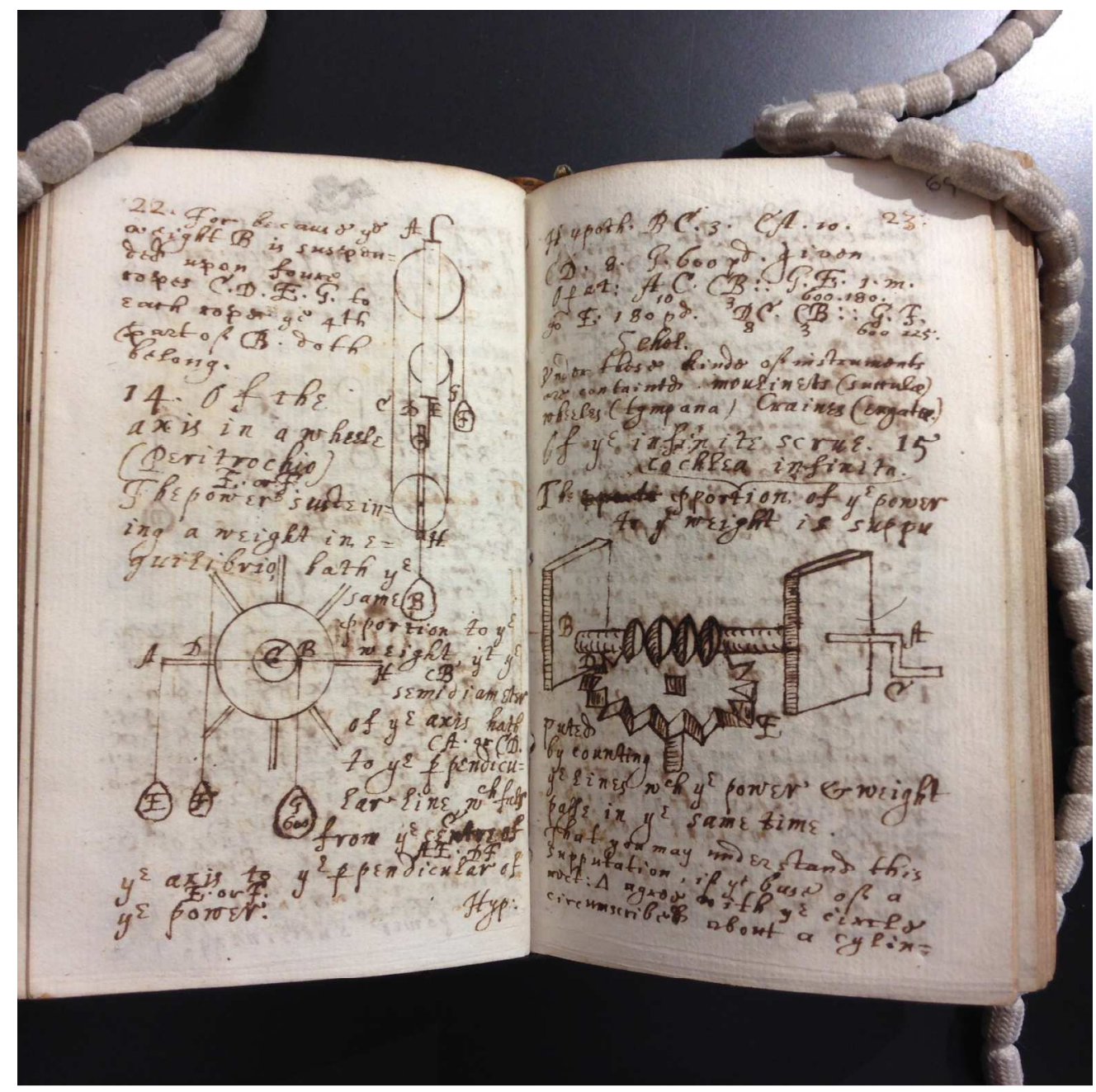

An opening from one of Rawlinson's mathematical compendia (Queen's College MS 430, fols. 68v-69r). The diagrams most likely derive from those in Guidobaldo del Monte's Mechanicorum liber (Pesaro, 1577).

$863 \times 863 \mathrm{~mm}(72 \times 72 \mathrm{DPI})$ 